from the non-classical student, whereby he might have been guided among apparently similar words of bewildering construction, and have seen at a glance, not only the grammatical value of the trivial name, but often the history of the determination of a species, now obscured in the featureless dog-Latin of ill-recognized nouns, and personal or geographical adjectives of doubtful aspect.

In the use of proper names it would be well if nomenclaturists would always apply the genitive in the case of the species being named after its discoverer; and the adjective form when some other relationship is in view, such as when a species is named in honour of some one connected.with the study of the group or of the locality.

Mr. Miller's Introduction on the Stratigraphy of the North-American Palæozoic rocks is full of information on the nature of the strata and their characteristic fossils, as elucidated by the many excellent geologists of the United States, Canada, Nova Scotia, \&c. The maximum thickness of the stratal groups constituting these old rocks, as here shown, is :-

Carboniferous strata. . . . . . . . . . . 24,100

Devonian . . . . . . . . . . . . . . 15,235

Upper Silurian . . . . . . . . . . . . . . 8, 8,000

Lower Silurian . . . . . . . . . . . 48,745

Huronian . . . . . . . . . . . . . . 20,000

Laurentian . . . . . . . . . . . 32,750

148,830

Even if the thickness of some of these groups be overestimated, and should portions of them be contemporaneous, yet, as some strata may have been omitted and others undervalued, the author thinks that the hypothetically vertical thickness of the whole is not likely to be less than 28 miles, and may be more, and that all but the lowest three miles are fossiliferous. He draws strong inferences as to the upspring and progress of the organic world by "processes of evolution and the survival of the fittest," and insists on the enormous lapse of time necessary for the accumulation of the strata under notice.

We are sure that this careful and well-printed Catalogue will be welcomed by all palæontologists ; and it will be especially useful in the comparative study of Silurian fossils as treated in Dr. Bigsby's 'Thesaurus Siluricus' (see Ann. \& Mag. Nat. Hist. ser. 4, vol. iii. pp. 314-317), and those of the Devonian and Carboniferous formations, amassed and annotated in his forthcoming elaborate volume devoted to those fossils.

\title{
MISCELLANEOUS.
}

Preliminary Notice of a Species of Phasmida apparently possessing all the Structural Arrangements needed both for Aerial and Aquatic Respiration. By J. Wood-Mason, F.G.S.

Mr attention has just been drawn by my friend Mr. Charles O. Waterhouse, of the British Museum, to a Phasmidan insect which, of the 
many remarkable forms of animal life that the great island of Borneo has yielded, is certainly not the least remarkable. The insect in question is closely related to the Prisopi* ${ }^{*}$, but is even more profoundly modified for an aquatic life ; for it breathes not only in the ordinary fashion amongst insects by means of tracheæ opening by stigmata on the exterior of the body, but also by the structures known as tracheal gills. From each side of its body, in fact, along the lower margins of the sides of the metathorax, there stand straight out five equal small but conspicuous ciliated oval plates, which, when the insect is submerged and its stigmata are closed, doubtless serve to bring the air that is thus shut up within the body into such intimate relation either with the oxygen dissolved in, or with the air in mechanical mixture with, the water as to render diffusion and consequently respiration possible.

The only other insect known to me in which during adult life ordinary aerial respiration and respiration by tracheal gills coexist is Pteronarcys regalis, one of the Orthoptera Amphibiotica.

For this remarkable form I beg to propose the name Cotylosoma dipneusticum.

The insect, which is a female with rudimentary organs of flight, is between three and four inches in length.

\section{Auriferous Sand in the Neighbourhood of the Seychelle Islands.}

By H. J. CarTer, F.R.S. \&c.

Belonging to the late Dr. Bowerbank was a little pill-box partly filled with sponge-spicules, and labelled "Dust from the Base of Dr. Farre's Euplectella, 26th Feb. 1857." This sponge, designated hy Prof. Owen "Euplectella cucumer," was stated by Dr. A. Farre (in whose possession it is or was) to have been "given with other presents, by the king of the Seychelle Islands, to Captain Etheridge, R.N., in acknowledgment of some friendly services, with an intimation that it was one of the rarest products of these regions " (Trans. Linn. Soc. vol. xxii. p. 122) ; and inferring, from actual experience ("Annals,' 1873, vol. xii. p. 463), that the "dust" would be found to contain a variety of spicule forms, indicative of so many of the sponges that must now live, or have lived, in this locality, it was boiled during six minutes in strong nitric acid to rid it from all calcareous and soft substances previously to mounting in Canada balsam for more deliberate observation with the microscope. Six slides were thus made, bearing material of different degrees of fineness, from the most subtle that conld be preserved to the coarsest in the box, when it was found to contain, as might have been expected, a quantity of sand (for the "dust" came from a mass of seabottom still held together in the root-spicules or beard of the Euplectella).

But what was most striking, when this sand (about, perhaps, a grain in weight) came to be examined, was the presence of minute

* For an account of the habits of these animals see Andrew Murray in Ann. \& Mag. Nat. Hist. 1866, 3rd ser. vol. xviii. p. 265. 